\title{
Short-term response in milk production, dry matter intake, and grazing behavior of dairy cows to changes in postgrazing sward height
}

\author{
E. Ganche, ${ }^{*} \dagger^{1}$ L. Delaby, $\neq$ M. O’Donovan, ${ }^{*}$ T. M. Boland, $\dagger$ and E. Kennedy ${ }^{\star}$ \\ *Teagasc, Animal and Grassland Research and Innovation Centre, Moorepark, Fermoy, Co. Cork, Ireland \\ †School of Agriculture and Food Science, University College Dublin, Belfield, Dublin, Ireland \\ fInstitut National de Recherche Agronomique, 35590 St. Gilles, France
}

\section{ABSTRACT}

Postgrazing sward height (PGSH) can be altered to adjust the allowance of grass in the dairy cow's diet. This study aimed to investigate the short-term dairy cow response to a change in postgrazing height in early lactation. Ninety Holstein Friesian spring-calving cows were randomly assigned across 3 postgrazing height treatments $(\mathrm{n}=30): 2.7 \mathrm{~cm}$ (severe), $3.5 \mathrm{~cm}$ (low), and $4.2 \mathrm{~cm}$ (moderate) from February 14 to April 24, 2011. From April 25, animals were rerandomized within each treatment to graze across 2 postgrazing heights: $3.5 \mathrm{~cm}$ (low) or $4.5 \mathrm{~cm}$ (high). Animal production measurements were taken from April 4 to 24 (measurement period 1; M1) and from April 25 to May 15 (measurement period 2; M2). The 6 treatments $(\mathrm{n}=15)$ of M2 were severe-low, severe-high, low-low, low-high, moderate-low, and moderate-high. During M1, increasing postgrazing height from severe to low to moderate linearly increased daily milk yield (21.5, 24.6 and 25.8 $\mathrm{kg} / \mathrm{cow}$ per day) and grass dry matter intake (GDMI; $13.2,14.9$, and $15.8 \mathrm{~kg}$ of DM/cow per day). Milk solids yield was reduced in the severe $(-1,518 \mathrm{~g} / \mathrm{cow}$ per day $)$ treatment when compared with the low and moderate cows $(1,866 \mathrm{~g} /$ cow per day, on average). The milk yield (MY) response to change in PGSH between M1 and M2 $\left(\mathrm{V}_{\mathrm{M} 1-\mathrm{M} 2}\right)$ was established using $\mathrm{V}_{\mathrm{M} 1-\mathrm{M} 2} \mathrm{MY}=-1.27-$ $1.89 \times \mathrm{PGSH}_{\mathrm{M} 1}+1.51 \times \mathrm{PGSH}_{\mathrm{M} 2}\left(\mathrm{R}^{2}=0.64\right)$. The MY response associated with each treatment between M1 and M2 (3 wk) were $-1.03 \mathrm{~kg} /$ cow for severe-low, $0.68 \mathrm{~kg} / \mathrm{cow}$ for severe-high, $-2.56 \mathrm{~kg} / \mathrm{cow}$ for low-low, $-1.11 \mathrm{~kg} /$ cow for low-high, $-4.17 \mathrm{~kg} /$ cow for moderatelow, and $-2.39 \mathrm{~kg} /$ cow for moderate-high. The large increase in energy intake in severe-high between M1 and M2 was achieved through higher GDMI per minute and GDMI per bite, which supported the positive change in MY. Treatments low-high, moderate-low, and moderate-high recorded the highest overall cumulative milk yield (74 kg of milk solids/cow) over the 6 -wk period,

Received September 10, 2013.

Accepted January 7, 2014.

${ }^{1}$ Corresponding author: elodie.ganche2@gmail.com whereas severe-low and severe-high had the lowest (65 $\mathrm{kg}$ of MS/cow). From the animal responses observed in the present study, imposing a postgrazing height of $3.5 \mathrm{~cm}$ in early spring provides the opportunity to increase postgrazing height thereafter; the cow increases GDMI accordingly and converts the additional energy intake into milk output. The equations established in this paper provide a decision tool for dairy farmers to anticipate the animal response when postgrazing height is altered or maintained around the tenth week of lactation.

Key words: dairy cow, postgrazing height, milk response, grazing

\section{INTRODUCTION}

Pasture-based dairy production systems aim to maximize the utilization of grazed grass to reduce the costs associated with feeding the dairy cow (Finneran et al., 2010). Increased farm profitability can be achieved by aligning the feed demand of the herd with grass growth (Dillon et al., 1995; Shalloo, 2009) so that grazed grass can comprise the majority of the diet during the lactation period. The greatest opportunity to increase the proportion of grazed grass in the dairy cow diet exists in early spring and late autumn periods, when grass growth is traditionally low in temperate climates (Roche et al., 2011). Ganche et al. (2013a,b) have shown that grazing to a postgrazing sward height (PGSH) of 3.5 $\mathrm{cm}$ is a strategy to increase grass availability during the early spring period; similar milk yield was produced compared with cows grazing to $4.2 \mathrm{~cm}$ following a 10wk period in early lactation. In northwest Europe, variability in grass growth can continue into late spring (early April), with annual fluctuations in grass supply dependent on the prevailing climatic conditions of a given year. For example, Hurtado-Uria et al. (2013) identified varying patterns of annual grass growth over a 20-yr period in South Ireland, as influenced by the meteorological factors including maximum, minimum, and mean air temperature, soil temperature, sunshine hours, solar radiation, and rainfall. To sustain the contribution of grazed grass in the diet, flexible graz- 
ing management responses are required to deal with fluctuations in grass supply.

Over short periods, suboptimal grass supply can be accommodated in the feed budget without adverse production effects (Ganche et al., 2013a,b); however, this may necessitate a reduction in PGSH. It is yet to be determined how dairy cows respond to short-term changes in PGSH that may occur in early lactation.

The dairy cow can respond to a reduction in feed supply by mobilizing body reserves and adjusting the nutrients partitioned toward milk production (Coulon et al., 1988; Nielsen et al., 2007; Delaby et al., 2009). Previous research has measured the effects of a change from a high- to low- and low- to high-nutrient supply on dairy cow performance (Grainger and Wilhelms 1979; Friggens et al., 1998; Nielsen et al., 2007). It was identified that dairy cows in early lactation responded to changes in the energy density of a TMR by increasing or decreasing DMI (Nielsen et al., 2007). When grass supply becomes sufficient in spring, PGSH can be increased to avail of a greater daily herbage allowance (DHA) for the dairy cow. Research results previously showed that the effect of early lactation DHA on midlactation animal production is temporary (Kennedy et al., 2007). In contrast, McEvoy et al. (2008) reported large carryover effects of early lactation DHA on midlactation protein content, BW change, and mean BCS. To our knowledge, no description of the short-term animal response to changes in grazing regimen has been reported.

Using PGSH as a grazing management tool is a strategy to influence both grass utilization and the animal's plane of nutrition. It is not clear how the dairy cow responds to changes in PGSH by varying DMI, or how the animal adjusts the partition of nutrients through the regulation of milk yield, body reserves, or a combination of the two. Focusing on the short-term period surrounding the change in PGSH will enhance the understanding of the dairy cow's response to changes in plane of nutrition.

The objective of this experiment was to assess the short-term adaptability of dairy cow performance to changes in plane of nutrition, via a change in PGSH, occurring around the tenth week of lactation. It was hypothesized that the change in performance is a function of the grazing regimen imposed preceding and following the change-over period.

\section{MATERIALS AND METHODS}

The experiment was conducted at the Animal and Grassland Research and Innovation Centre, Teagasc, Moorepark, Fermoy, Co. Cork, Ireland $\left(50^{\circ} 16^{\prime} \mathrm{N}\right.$; $\left.8^{\circ} 25^{\prime} \mathrm{W}\right)$. The soil type was a free-draining acid brown earth of sandy loam-to-loam texture. The area used was under permanent pasture with a predominately perennial ryegrass sward (Lolium perenne L.). The swards were, on average, $6 \mathrm{yr}$ old. This experiment was part of a larger study conducted from February 14 to November 13, 2011. A full description of the experimental design, pasture measurements, and total lactation animal production has previously been reported by Ganche et al. (2013b).

\section{Experimental Design, Treatments, and Animals}

The current experiment was conducted as a randomized block design with a $3 \times 2$ factorial arrangement of treatments. Before the experiment, 90 Holstein Friesian dairy cows (27 primiparous and 63 multiparous) were selected and blocked on calving date, lactation number, BCS and BW, dam's first lactation milk yield and composition for the primiparous cows, and previous lactation milk yield and composition for the multiparous cows (Ganche et al., 2013b). Animals were randomly assigned precalving to 1 of $3 \mathrm{PGSH}$ treatments $(\mathrm{n}=$ 30 ): severe $(\mathbf{S})=2.7 \mathrm{~cm}$, low $(\mathbf{L})=3.5 \mathrm{~cm}$, or moderate $(\mathbf{M}) 4.2 \mathrm{~cm}$. Actual mean calving date was February $13,2011(\mathrm{SD}=18 \mathrm{~d})$. Treatments were imposed from February 14 to April 24 (change-over date). Prior to the change-over date, animals were rerandomized within their initial treatment on the basis of the 3 -wk animal performance before change-over (Ganche et al., 2013b). Animals were balanced into 2 groups and assigned to graze to either the target PGSH of 3.5 (low) or $4.5 \mathrm{~cm}$ (high) from April 25 to November 13.

The present paper focuses on the period from April 4 to May 15, 2011, 3 wk immediately before and $3 \mathrm{wk}$ immediately after the change-over date. Milk production and composition, BW, BCS, grass DMI (GDMI), grazing behavior, and blood metabolites were measured during measurement period 1 (M1; April 4-24) and measurement period 2 (M2; April 25-May 15). The experimental treatments in M1 $(\mathrm{S}, \mathrm{L}$, and $\mathrm{M})$ and in M2 (S-Low, S-High, L-Low, L-High, M-Low, and M-High) are detailed in Figure 1. The results of the full lactation study have previously been published by Ganche et al. (2013b).

\section{Grazing Management and Sward Measurements}

The grazing management applied during M1 and M2 followed the grazing management rules imposed in the larger study (Ganche et al., 2013b). Briefly, each paddock grazed to 1 of 3 PGSH treatments during M1 was subdivided into 2 equal areas (subpaddocks) after the change-over date (April 25), with each subpaddock being grazed to either 3.5 or $4.5 \mathrm{~cm}$ for the 


\begin{tabular}{|c|c|c|c|}
\hline Target PGSH & \multicolumn{3}{|c|}{ Paddock Division } \\
\hline In $M 1$ & $\begin{array}{c}2.7 \mathrm{~cm} \\
\mathrm{~S}\end{array}$ & $\begin{array}{c}3.5 \mathrm{~cm} \\
\mathbf{L}\end{array}$ & $\begin{array}{c}4.2 \mathrm{~cm} \\
\mathbf{M}\end{array}$ \\
\hline In $M 2$ & $\begin{array}{l:c}3.5 \mathrm{~cm} & 4.5 \mathrm{~cm} \\
\text { S-Low } & \text { S-High }\end{array}$ & 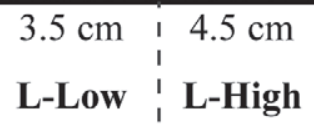 & $\begin{array}{c:c}3.5 \mathrm{~cm} & 4.5 \mathrm{~cm} \\
\text { M-Low } & \text { M-High }\end{array}$ \\
\hline
\end{tabular}

Figure 1. Experimental treatments during measurement periods 1 (M1; April 4-24) and 2 (M2; April 25-May 15). PGSH = postgrazing sward height; $\mathrm{S}=$ severe; $\mathrm{L}=$ low; $\mathrm{M}=$ moderate.

duration of M2. Rotational grazing was applied and treatment herds were managed independently, stocked at 2.74 cows/ha. Animals were offered fresh grass by using temporary electric fences, following each a.m. and p.m. milking in M1 and on a 24-h basis (following each a.m. milking) in M2, due to drier ground conditions. Concentrate was offered to cows across all treatments for the first $5 \mathrm{~d}$ of $\mathrm{M} 1(2.7 \mathrm{~kg}$ of $\mathrm{DM} /$ cow per day, on average) and was not continued thereafter. Twice weekly, pre- and postgrazing herbage mass (HM) was estimated by cutting 2 strips per paddock using a motor Agria (Etesia UK Ltd., Warwick, UK; Ganche et al., 2013b) and corrected above $2.7 \mathrm{~cm}$ in M1 and above $3.5 \mathrm{~cm}$ in $\mathrm{M} 2$ as

M1 Pregrazing HM (kg of DM/ha) = [Pregrazing sward height $(\mathrm{cm})-2.7 \mathrm{~cm}] \times\{\mathrm{HM}(\mathrm{kg}$ of DM/ha $) /$ [precutting height $(\mathrm{cm})-$ postcutting height $(\mathrm{cm})]\}$, or

M2 Pregrazing HM (kg of DM/ha) = [Pregrazing sward height $(\mathrm{cm})-3.5 \mathrm{~cm}] \times\{\mathrm{HM}(\mathrm{kg}$ of $\mathrm{DM} / \mathrm{ha}) /$ [precutting height $(\mathrm{cm})$ - postcutting height $(\mathrm{cm})]\}$.

Mean pre- and postgrazing sward heights were measured daily throughout the experiment using a folding pasture plate meter $\left(355 \mathrm{~mm}\right.$ and $3.2 \mathrm{~kg} / \mathrm{m}^{2}$ in diameter; Jenquip, Fielding, New Zealand; Ganche et al., 2013b). Postgrazing sward heights were measured before cows returned to the paddock following morning milking. If the target PGSH was not achieved, animals remained in the previous day's grazing area until they grazed to their PGSH. Daily herbage allowance was calculated as a product of the area offered to the herd and the pregrazing HM.

\section{Herbage Analysis}

The diet of animals was sampled weekly during M1 and M2. Herbage representative of that grazed was manually collected using Gardena hand shears (Accu 60, Gardena International GmbH, Brampton, Canada), following close observation of the height herbage was defoliated to by the grazing animals the previous day. Samples were stored at $-20^{\circ} \mathrm{C}$ before being freeze-dried, milled through a 1-mm screen, and bulked by treatment for each measurement period before conducting chemical analysis. Herbage samples were analyzed for DM, ash (AOAC International, 1995; method 942.05), ADF and NDF (AOAC International, 1995; method 973.18; using sodium sulfate for NDF; ANKOM technology, Macedon, NY), CP (Leco FP-428; Leco Australia Pty Ltd., Castle Hill, Australia), and organic matter digestibility (OMD; method used by Morgan et al. 1989; Fibertec Systems, Foss, Ballymount, Dublin, Ireland).

\section{Animal Measurements}

Milk Production, Milk Composition, BW, and $\boldsymbol{B C S}$. Individual milk yields were recorded at 0700 and $1600 \mathrm{~h}$ daily (Dairymaster, Causeway, Co. Kerry, Ireland). Milk fat, protein, and lactose concentrations were determined weekly from the successive Tuesday p.m. and Wednesday a.m. milking samples for each animal. The concentrations of these constituents in the milk were determined by using a MilkoScan 203 (Foss Electric DK, Hillerød, Denmark). Milk solids yield was calculated from the sum of milk fat yield and milk protein yield (kilograms of milk solids yield per cow). Body weight and BCS were recorded weekly throughout the experimental period. An electronic portable weighing scale with the Winweigh software package (Tru-test Limited, Auckland, New Zealand) was used to record BW. Body condition was scored by the same individual throughout the study on a scale from 1 to 5 (where $1=$ emaciated and $5=$ extremely fat) with 0.25 increments (Lowman et al., 1976).

Intake Estimation. Individual GDMI was measured once during M1 and once during M2 using the n-alkane technique (Dillon and Stakelum, 1989). All cows were dosed twice daily for $12 \mathrm{~d}$ before both morning and 
evening milking with a paper pellet (Carl Roth $\mathrm{GmbH}$, Karlesruhe, Germany) containing $500 \mathrm{mg}$ of dotriacontane (C32-alkane). From d 7 to 12 of dosing, feces samples were collected from each cow twice daily before both morning and evening milking and stored at $-20^{\circ} \mathrm{C}$. The feces samples were then thawed and bulked (12 g of each collected sample) by cow and dried for $48 \mathrm{~h}$ in a $60^{\circ} \mathrm{C}$ oven. Samples were then milled through a $1-\mathrm{mm}$ screen and stored for chemical analysis. During the period of feces collection, the diet of the animals was also sampled. Herbage samples were manually collected with Gardena hand shears (as previously described) with the same methodology used for the chemical analysis of weekly herbage samples. The ratio of herbage C33 to dosed C32 was used to estimate intake. The n-alkane concentration of the dosed pellets, feces, and herbage were determined as described by Dillon (1993).

Grazing Behavior. The grazing behavior measurements were concurrent with the M1 and M2 GDMI measurements. Grazing behavior data were collected from 16 cows on each of the M1 treatments and from 8 cows on each of the M2 treatments. Data collection was repeated twice per measurement period for each cow over a 24 -h period. Following the morning milking, 5 cows from each M1 PGSH treatment (3 cows from each M2 treatment, during M2) were fitted with Institute of Grassland and Environmental Research behavior recorders (Rutter et al., 1997). Following recording, jaw movements were analyzed using Graze analysis software (Rutter, 2000). If the recorded data file obtained from a cow was not satisfactorily readable, the cow had a recorder fitted for a further 24 -h period. Total grazing, ruminating, and idling times, as well as the number of prehensions and mastications, were measured using this software. In addition, the number of grazing and ruminating bouts and the number of boli within each ruminating bout were counted. Intake per minute (grams of DM per minute) was calculated as [GDMI $(\mathrm{kg} / \mathrm{d}) \times$ $1,000]$ /grazing time; intake per bite was calculated as [GDMI $(\mathrm{kg} / \mathrm{d}) \times 1,000] /$ grazing prehensions per day.

Energy Balance. The net energy value required for maintenance, growth, and milk production (expressed as unité fourragère lait; UFL) was calculated for each individual cow at each measurement period according to equations described by Faverdin et al. (2007). A UFL requirement for growth was included in the calculation for cows less than 40 mo old. Maintenance requirement was quantified by using the average weekly BW of the animal. Milk energy output resulted from milk yield and contents of mean fat, protein, and lactose of 2 weekly samples. The UFL of the feed was calculated using the OMD values of the herbage offered (Beaumont et al., 2007). Energy balance of each cow was calculated as the difference between estimated UFL intake and estimated UFL requirement.

Blood Sampling. Blood samples were taken from each cow once during M1 (59 DIM; change-over date 12) and once during M2 (80 DIM; change-over date + 9). Sampling took place following a.m. milking. Blood samples were taken from the coccygeal vessel into one 10-mL lithium heparinized glass tube (Vacutainer, Becton Dickinson, Plymouth, UK). Samples were centrifuged within $1 \mathrm{~h}$ of collection at 3,000 $\times g$ for $10 \mathrm{~min}$ at $5^{\circ} \mathrm{C}$. Following decantation, the plasma was split into borosilicate glasses and stored at $-20^{\circ} \mathrm{C}$ until analysis. Blood plasma was then analyzed for metabolites, including glucose, BHBA, and NEFA. Concentrations of glucose, BHBA, and NEFA were determined by enzymatic calorimetry using an ABX Mira Auto analyzer (ABX Mira, Montpellier, France).

\section{Statistical Analyses}

All statistical analyses were carried out using SAS software (SAS Institute Inc., Cary, NC). Herbage data were analyzed by ANOVA using terms for treatment and week (Ganche et al., 2013b). Milk production and composition, BW, BCS, DMI, grazing behavior data, energy balance, and plasma metabolites variables in M1 and M2 were analyzed by covariate analysis using PROC MIXED, with the following models for each period:

$$
\begin{gathered}
\mathrm{M} 1 \mathrm{Y} 1_{i j}=\mu+\mathrm{P}_{i}+\mathrm{H}_{j}+\mathrm{P}_{i} \times \mathrm{H} 1_{j} \\
+\mathrm{b}_{1} \mathrm{X} 1_{i j}+\mathrm{b}_{2} \mathrm{DIM}_{i j}+e_{i j} \text {, and } \\
\mathrm{M} 2 \mathrm{Y}_{i j k}=\mu+\mathrm{P}_{i}+\mathrm{H} 1_{j}+\mathrm{H} 2_{k}+\left(\mathrm{H} 1_{j} \times \mathrm{H} 2_{k}\right) \\
+\mathrm{b}_{1} \mathrm{X} 2_{i j k}+\mathrm{b}_{2} \mathrm{DIM}_{i j k}+e_{i j k},
\end{gathered}
$$

where $\mathrm{Y} 1_{i j}$ and $\mathrm{Y} 2_{i j k}=$ the response of animal in parity $i$ to treatment $j$ (and treatment $k$ in M2), respectively; $\mu=$ mean; $\mathrm{P}_{i}=$ parity $(i=1$ to 2$) ; \mathrm{H}_{j}=\mathrm{M} 1 \mathrm{PGSH}$ treatment $(j=1$ to 3$) ; \mathrm{H} 2_{k}=\mathrm{M} 2 \mathrm{PGSH}$ treatment $(k$ $=1$ to 2$) ; \mathrm{H} 1_{j} \times \mathrm{H} 2_{k}=$ the interaction between M1 treatment and M2 treatment; $\mathrm{b}_{1} \mathrm{X} 1_{i j}$ and $\mathrm{b}_{2} \mathrm{X} 2_{i j k}=$ the preexperimental variable in $\mathrm{M} 1$ and $\mathrm{M} 2$, respectively; $\mathrm{b}_{2} \mathrm{DIM}_{i j k}=$ the DIM at change-over; and $e_{i j k}=$ the residual error term. The interactions between parity and M1 treatment, parity and M2 treatment, and parity, M1 treatment, and M2 treatment were removed from the model because their effects were not significant. Prior to the analysis of M1 animal data, the preexperimental variables (previous lactation or dam's first lactation milk yield, milk composition, BW, or BCS) 
were centered within parity before inclusion. Preexperimental variables in M2 were the mean milk yield, milk composition, BW, and BCS during M1 for each variable. These covariates were first centered within parity and M1 PGSH treatment before inclusion. Days in milk was the only covariate used to analyze the DMI and plasma metabolites data from M1 and M2.

The change in milk, milk protein, fat, and lactose yields between M1 and M2 (3 wk) were calculated per cow, by the difference of mean M2 yield and M1 yield and using covariate analysis (PROC MIXED) with terms for parity, PGSH treatment in M1, PGSH treatment in M2, and the covariate production variable during M1 first centered within parity and M1 treatment. The interactions between parity and M1 treatment, parity and M2 treatment, and parity, M1 treatment, and M2 treatment were never significant, therefore they were not included in the model. Because PGSH treatments in M1 and M2 are 2 quantitative factors, the previous model was rewritten with one factor $\left(\mathrm{P}_{i}\right)$ and 3 covariates $\left(\mathrm{H} 1, \mathrm{H} 2\right.$, and $\left.\mathrm{b}_{1} \mathrm{X} 2_{i j k}\right)$ as

$$
\mathrm{V}_{i j k}=\mu+\mathrm{P}_{i}+\mathrm{a}_{1} \mathrm{H} 1+\mathrm{a}_{2} \mathrm{H} 2+\mathrm{b}_{1} \mathrm{X} 2_{i}+e_{i},
$$

where $\mathrm{V}_{i j k}=$ the milk response of animal in parity $i(i$ $=1,2) ; \mathrm{a}_{1}$ and $\mathrm{a}_{2}$ are the slopes for the parameters $\mathrm{H} 1$ and $\mathrm{H} 2$, respectively; $\mathrm{H} 1$ = the PGSH imposed in M1; $\mathrm{H} 2=$ the PGSH imposed in $\mathrm{M} 2 ; \mathrm{b}_{1} \mathrm{X} 2_{i}=$ the respective milk yield or milk component yield before M2 (i.e., during M1); and $e_{i}=$ residual error term. The equation coefficients from this analysis are presented in the results and allow the prediction of milk yield and milk constituent yield response to changes in PGSH.

Plasma metabolites in M1, M2, and the change between M1 and M2 were analyzed by covariate analysis (PROC MIXED), using the covariate DIM. Before the analysis of plasma metabolite variables, the square root transformation of NEFA and the box-cox transformation of BHBA were used to normalize the distributions. Analysis was undertaken on the transformed, normally distributed data; the back-transformed results are presented.

\section{RESULTS}

\section{Grass Composition}

No difference was observed between PGSH treatments in composition of the consumed herbage in M1 for ash [81, standard error of the difference (SED) 3.16 $\mathrm{g} / \mathrm{kg}$ of DM], CP (214, SED $3.9 \mathrm{~g} / \mathrm{kg}$ of DM), NDF (501, SED $19.0 \mathrm{~g} / \mathrm{kg}$ of DM), ADF (276, SED $8.6 \mathrm{~g} /$ $\mathrm{kg}$ of DM), OMD (814, SED $27.3 \mathrm{~g} / \mathrm{kg}$ of DM), or UFL (1.04, SED 0.04) contents. In M2, the composition of the consumed herbage was also similar across treatments for ash (82, SED $3.4 \mathrm{~g} / \mathrm{kg}$ of DM), CP (223, SED $14.2 \mathrm{~g} / \mathrm{kg}$ of DM), NDF (514, SED $27.3 \mathrm{~g} / \mathrm{kg}$ of DM), ADF (245, SED $10.4 \mathrm{~g} / \mathrm{kg}$ of DM), OMD (803, SED $22.0 \mathrm{~g} / \mathrm{kg}$ of DM), and UFL (1.0, SED 0.05) contents.

\section{Sward Measurements}

The pre- and postgrazing pasture characteristics in M1 and M2 are presented in Table 1. During M1, actual PGSH achieved were 2.7, 3.6, and $4.4 \mathrm{~cm}$, for S, L, and $\mathrm{M}$, respectively, compared with targets of $2.5,3.5$, and $4.5 \mathrm{~cm}$. Daily herbage allowance (above $2.7 \mathrm{~cm}$ ) increased $(P<0.001)$ and grass utilization decreased $(P<0.001)$ from $\mathrm{S}$ to $\mathrm{L}$ and further to M. In M2, the low and high treatments achieved a mean PGSH of 3.6 and $4.7 \mathrm{~cm}$, respectively, with a mean DHA of 15.0 and $17.1 \mathrm{~kg}$ of $\mathrm{DM} /$ cow per day, respectively.

\section{Milk Yield and Milk Composition}

The milk yield and milk components yields during M1 and M2 are shown in Table 2. During M1, milk yield, milk protein, and lactose yields significantly increased $(P<0.001)$ from $\mathrm{S}$ to $\mathrm{L}$, and further to M. Animals in $\mathrm{S}$ had lower $(P<0.001)$ milk fat yield $(835 \mathrm{~g} / \mathrm{d})$ and milk solids yield $(1.52 \mathrm{~kg} / \mathrm{d})$ than animals in $\mathrm{L}$ and $\mathrm{M}$, which performed similarly $(1,032 \mathrm{~g} / \mathrm{d}$ and 1.87 $\mathrm{kg} / \mathrm{d}$, respectively). Animals in S also had lower milk fat $(38.3 \mathrm{~g} / \mathrm{kg})$ and protein $(31.8 \mathrm{~g} / \mathrm{kg})$ concentrations $(P<0.001)$ than animals in $\mathrm{L}$ and $\mathrm{M}$, which did not differ significantly (41.0 and $33.0 \mathrm{~g} / \mathrm{kg}$, respectively). Treatment in M1 did not affect milk lactose concentration $(47.7 \mathrm{~g} / \mathrm{kg})$. Animals in the high treatment of M2 had greater $(P<0.001)$ milk yield $(+1.7 \mathrm{~kg} / \mathrm{d})$, yields of fat $(+78 \mathrm{~g} / \mathrm{d})$, protein $(+58 \mathrm{~g} / \mathrm{d})$, lactose $(+71 \mathrm{~g} / \mathrm{d})$, and milk solids $(+0.14 \mathrm{~kg} / \mathrm{d})$ than in the low treatment $(21.2 \mathrm{~kg} / \mathrm{d}, 855 \mathrm{~g} / \mathrm{d}, 698 \mathrm{~g} / \mathrm{d}, 1,013 \mathrm{~g} / \mathrm{d}$, and 1.55 $\mathrm{kg} / \mathrm{d}$, respectively). No difference was noted in milk fat $(40.5 \mathrm{~g} / \mathrm{kg})$, protein $(32.9 \mathrm{~g} / \mathrm{kg})$, and lactose $(47.5 \mathrm{~g} /$ $\mathrm{kg})$ concentrations across M2 treatments.

The equations predicting the change in yields of milk and milk components between M1 and M2 (total milk yield change over $3 \mathrm{wk}$ ) are presented in Table 3. The slope $a_{1}$ represents the yield change when PGSH in M1 increases by $1 \mathrm{~cm}$; the slope $\mathrm{a}_{2}$ represents the yield change when PGSH in M2 increases by $1 \mathrm{~cm}$. For example, the milk yield change between M1 and M2 can be found using $\mathrm{V}_{\mathrm{M} 1-\mathrm{M} 2}$ milk yield $=-1.27-1.89 \times$ $\mathrm{PGSH}_{\mathrm{M} 1}+1.51 \times \mathrm{PGSH}_{\mathrm{M} 2}$. From the regression coefficients presented in Table 3, it can be concluded that independent of PGSH imposed in $\mathrm{M} 2$, a $1 \mathrm{~cm}$ increase in PGSH during M1 results in a decrease of $1.89 \mathrm{~kg}$ of milk/cow milk yield change, which is equivalent to a 
Table 1. Effect of postgrazing sward height (PGSH) on sward measurements during measurement period 1 (M1; April 4-24) and 2 (M2; April 25-May 15)

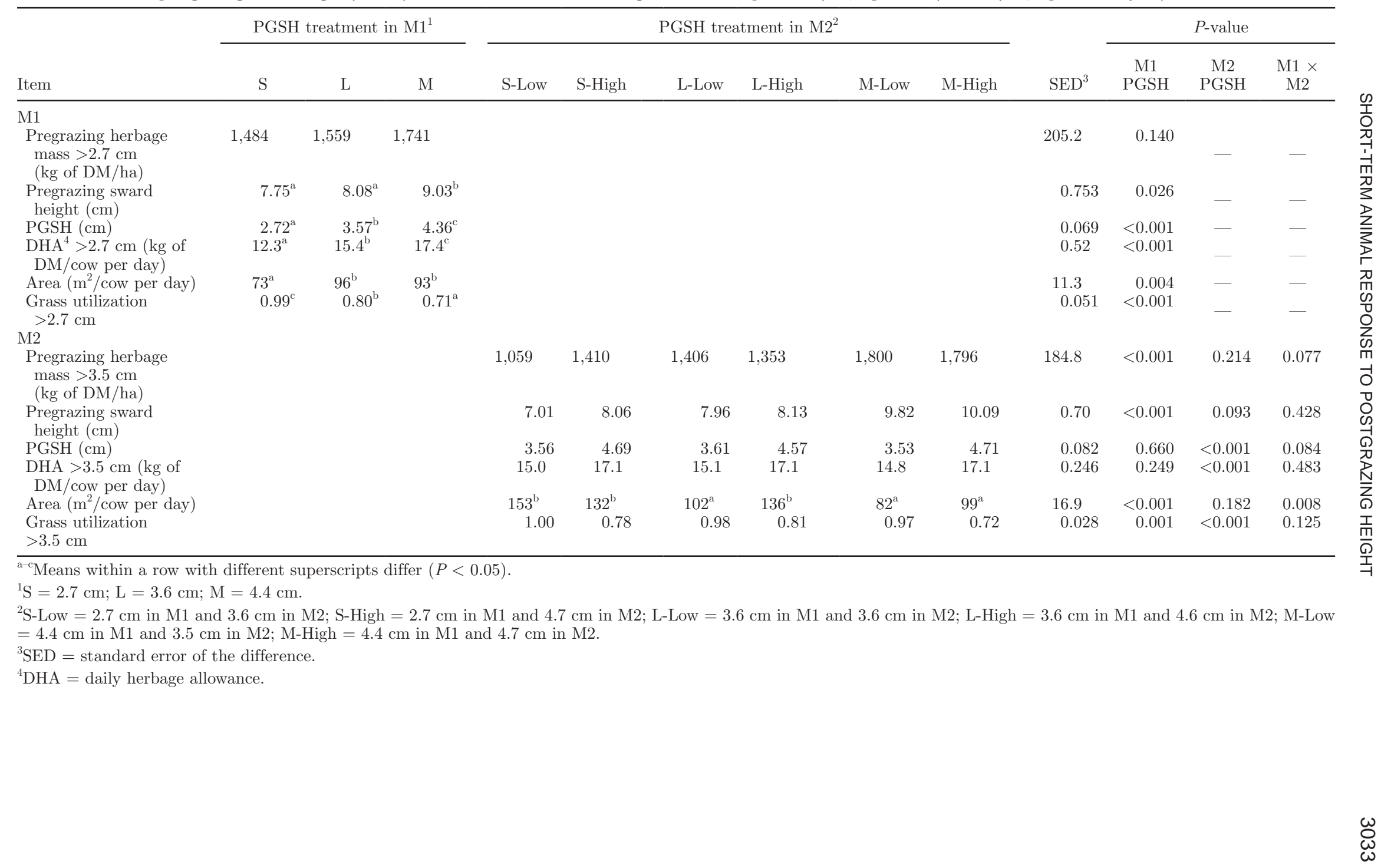


Table 2. Effect of postgrazing sward height (PGSH) on milk yield, milk component yields, and DMI during measurement period 1 (M1; April 4-24) and 2 (M2; April 25-May 15)

M1

Milk yield $(\mathrm{kg} / \mathrm{d})$

Fat yield (g/d)

Protein yield $(\mathrm{g} / \mathrm{d})$

Lactose yield $(\mathrm{g} / \mathrm{d})$

(g/d)

Grass DMI

$(\mathrm{kg}$ of $\mathrm{DM} / \mathrm{d})$

$\mathrm{UFL}^{4}$ intake (per

cow $/$ d)

Energy balance

(UFL/cow per day)

\begin{tabular}{crr}
\multicolumn{3}{c}{ PGSH treatment in $\mathrm{M}^{1}$} \\
\hline $\mathrm{S}$ & $\mathrm{L}$ & $\mathrm{M}$ \\
$21.5^{\mathrm{a}}$ & $24.6^{\mathrm{b}}$ & $25.8^{\mathrm{c}}$ \\
$834^{\mathrm{a}}$ & $1,024^{\mathrm{b}}$ & $1,039^{\mathrm{b}}$ \\
$684^{\mathrm{a}}$ & $809^{\mathrm{b}}$ & $858^{\mathrm{c}}$ \\
$1,025^{\mathrm{a}}$ & $1,168^{\mathrm{b}}$ & $1,232^{\mathrm{c}}$ \\
$1,518^{\mathrm{a}}$ & $1,834^{\mathrm{b}}$ & $1,897^{\mathrm{b}}$ \\
$13.2^{\mathrm{a}}$ & $14.9^{\mathrm{b}}$ & $15.8^{\mathrm{c}}$ \\
$13.7^{\mathrm{a}}$ & $15.5^{\mathrm{b}}$ & $16.5^{\mathrm{c}}$ \\
-1.2 & -1.4 & -1.0
\end{tabular}

M2

Milk yield $(\mathrm{kg} / \mathrm{d})$

Fat yield (g/d)

Protein yield $(\mathrm{g} / \mathrm{d})$

Lactose yield $(\mathrm{g} / \mathrm{d})$

Milk solids yield

(g/d)

Grass DMI (kg of

$\mathrm{DM} / \mathrm{d}$ )

UFL intake (per

cow/d)

Energy balance

(UFL/cow per day)

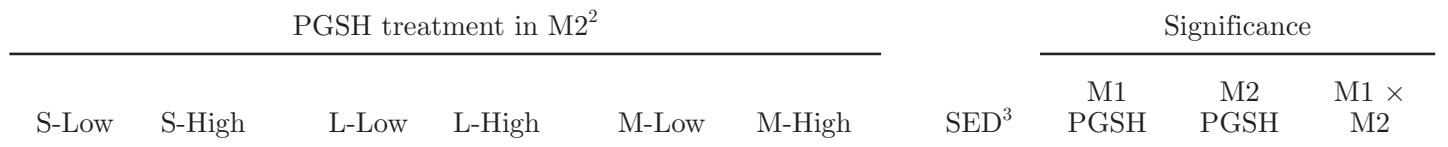

${ }^{\mathrm{ac}}$ Means within a row with different superscripts differ $(P<0.05)$.

${ }^{1} \mathrm{~S}=2.7 \mathrm{~cm} ; \mathrm{L}=3.6 \mathrm{~cm} ; \mathrm{M}=4.4 \mathrm{~cm}$.

${ }^{2} \mathrm{~S}-\mathrm{Low}=2.7 \mathrm{~cm}$ in M1 and $3.6 \mathrm{~cm}$ in M2; S-High $=2.7 \mathrm{~cm}$ in M1 and $4.7 \mathrm{~cm}$ in M2; L-Low $=3.6 \mathrm{~cm}$ in M1 and $3.6 \mathrm{~cm}$ in M2; L-High $=3.6 \mathrm{~cm}$ in M1 and $4.6 \mathrm{~cm}$ in M2; M-Low

$=4.4 \mathrm{~cm}$ in $\mathrm{M} 1$ and $3.5 \mathrm{~cm}$ in M2; M-High $=4.4 \mathrm{~cm}$ in M1 and $4.7 \mathrm{~cm}$ in M2

${ }^{3} \mathrm{SED}=$ standard error of the difference.

${ }^{4} \mathrm{UFL}=$ growth and milk production (expressed as unité fourragère lait). 
Table 3. Equations to predict milk yield and milk composition change $\left(\mathrm{V}_{\mathrm{M} 1-\mathrm{M} 2}\right)$ in accordance with changes in postgrazing sward height (PGSH) between measurement period 1 (M1; April 4-24) and 2 (M2; April 25-May $15)^{1}$



weekly change of $-0.63 \mathrm{~kg}$ of milk/cow. Independent of PGSH imposed in M1, a $1 \mathrm{~cm}$ increase in PGSH in M2 results in a milk yield increase of $1.51 \mathrm{~kg} /$ cow during $\mathrm{M} 2$, which is equivalent to a weekly reduction of 0.50 $\mathrm{kg}$ of milk/cow.

Because of the lack of interaction between M1 PGSH and M2 PGSH treatment effects, the effects are cumulative and offer the opportunity to anticipate the increase or decrease in milk production and milk composition between M1 and M2 by using the 2 quantitative parameters, that is, PGSH in M1 and PGSH in M2. For the treatment S-Low, for example, the variation in milk yield between M1 and M2 (3 wk) equated to -1.04 $\mathrm{kg}$ of milk/cow or a weekly change of $-0.35 \mathrm{~kg} / \mathrm{cow}$. The individual milk and milk solids production changes for the 6 treatments are given in Table 4; the average daily milk and milk solids yields (kilograms per cow per day) for each week of the experiment are illustrated in Figure 2.

\section{Cumulative Milk and Milk Solids Production}

At the end of M1, cumulative milk yield was $452 \mathrm{~kg} /$ cow for S treatment cows, which increased to 516 and to $541 \mathrm{~kg}$ of milk/cow for the $\mathrm{L}$ and $\mathrm{M}$ treatments, respectively $(P<0.001)$. Milk solids yield for the $\mathrm{S}$ animals was less $(P<0.01 ; 32 \mathrm{~kg} / \mathrm{cow})$ than that of the $\mathrm{L}$ and $\mathrm{M}$ animals, which were similar $(39 \mathrm{~kg} / \mathrm{cow})$.

No interaction between M1 and M2 PGSH treatments on M2 cumulative milk and milk solids yields was observed. The cows in the high treatments in M2 produced $(P<0.001) 35 \mathrm{~kg}$ of milk/cow more than cows in the low (446 kg of milk/cow) treatments. The L cows during M1 recorded the greatest cumulative milk yield in M2 $(487 \mathrm{~kg} /$ cow; $P<0.001)$, followed by the $\mathrm{M}$ cows $(464 \mathrm{~kg} / \mathrm{cow})$, and then $\mathrm{S}$ cows $(440 \mathrm{~kg} / \mathrm{cow})$. The 6 -wk cumulative milk yields were similar across the 6 treatments of M2 $(963 \mathrm{~kg} / \mathrm{cow})$; a tendency $(P=$ 0.07 ) was noted for greater cumulative milk solids yield on the L-High, M-Low, and M-High treatments $(74 \mathrm{~kg} /$ cow, on average), whereas lowest milk solids yields were recorded in S-Low and S-High $(65 \mathrm{~kg} / \mathrm{cow})$ and L-Low was intermediate.

\section{Grass Intake}

The GDMI values for each treatment in M1 and M2 are presented in Table 2. During M1, increasing

Table 4. Effect of change in postgrazing sward height (PGSH) on the short-term response in milk yield and milk component yields $\left(\mathrm{V}_{\mathrm{M} 1-\mathrm{M} 2}{ }^{1}\right)$ between measurement period 1 (M1; April 4-24) and 2 (M2; April 25-May 15)

\begin{tabular}{|c|c|c|c|c|c|c|c|c|c|c|}
\hline \multirow[b]{2}{*}{ Item } & \multicolumn{6}{|c|}{ PGSH treatment $^{2}$} & \multirow[b]{2}{*}{$\mathrm{SED}^{3}$} & \multicolumn{3}{|c|}{$P$-value } \\
\hline & S-Low & S-High & L-Low & L-High & M-Low & M-High & & $\begin{array}{c}\text { M1 } \\
\text { PGSH }\end{array}$ & $\begin{array}{c}\text { M2 } \\
\text { PGSH }\end{array}$ & $\begin{array}{c}\text { M1 } \times \\
\text { M2 }\end{array}$ \\
\hline $\mathrm{V}_{\mathrm{M} 1-\mathrm{M} 2}$, milk yield $(\mathrm{kg})$ & -1.03 & 0.68 & -2.56 & -1.11 & -4.17 & -2.39 & 0.305 & $<0.001$ & $<0.001$ & 0.613 \\
\hline $\mathrm{V}_{\mathrm{M} 1-\mathrm{M} 2}$, fat yield $(\mathrm{g})$ & -11.5 & 73.2 & -95.7 & -23.7 & -183.3 & -94.8 & 20.94 & $<0.001$ & $<0.001$ & 0.165 \\
\hline $\mathrm{V}_{\mathrm{M} 1-\mathrm{M} 2}$, protein yield $(\mathrm{g})$ & -18.5 & 42.1 & -80.5 & -29.1 & -145.0 & -81.7 & 10.74 & $<0.001$ & $<0.001$ & 0.155 \\
\hline $\mathrm{V}_{\mathrm{M} 1-\mathrm{M} 2}$, lactose yield (g) & -54.6 & 15.3 & -121.8 & -62.4 & -192.0 & -119.0 & 15.92 & $<0.001$ & $<0.001$ & 0.549 \\
\hline
\end{tabular}

${ }^{1}$ The variations in yields between M1 and M2 (3 wk) have been calculated from the equations presented in Table 3.

${ }^{2} \mathrm{~S}-\mathrm{Low}=2.7 \mathrm{~cm}$ in M1 and $3.6 \mathrm{~cm}$ in M2; S-High $=2.7 \mathrm{~cm}$ in M1 and $4.7 \mathrm{~cm}$ in M2; L-Low $=3.6 \mathrm{~cm}$ in M1 and $3.6 \mathrm{~cm}$ in M2; L-High $=3.6$ $\mathrm{cm}$ in M1 and $4.6 \mathrm{~cm}$ in M2; M-Low $=4.4 \mathrm{~cm}$ in M1 and $3.5 \mathrm{~cm}$ in M2; M-High $=4.4 \mathrm{~cm}$ in M1 and $4.7 \mathrm{~cm}$ in M2.

${ }^{3} \mathrm{SED}=$ standard error of the difference. 

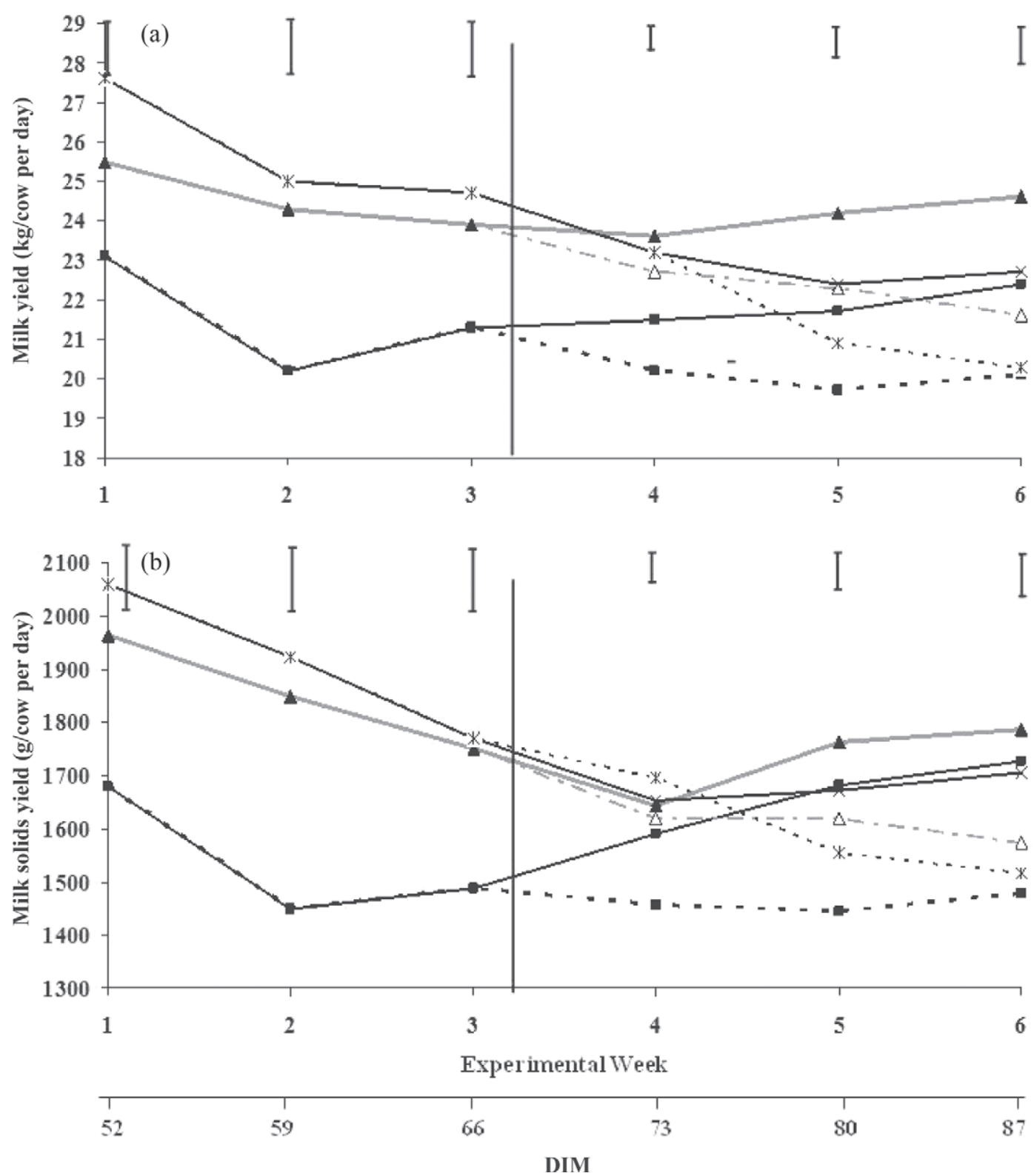

Figure 2. Average daily milk yield (a; $\mathrm{kg} / \mathrm{cow}$ per day) and milk solids yield (b;g/cow per day) for each week during measurement period 1 (M1; wk 1-3; April 4-24) and 2 (M2; wk 4-6; April 25-May 15) for each postgrazing sward height treatment. The vertical line following wk 3 indicates the time of change-over. S-Low (dotted line, $)=2.7 \mathrm{~cm}$ in M1 and $3.6 \mathrm{~cm}$ in M2; S-High (full line, $\mathbf{0})=2.7 \mathrm{~cm}$ in M1 and $4.7 \mathrm{~cm}$ in M2; L-Low (dotted gray line, $\Delta$ ) $=3.6 \mathrm{~cm}$ in M1 and $3.6 \mathrm{~cm}$ in M2; L-High (full gray line, $\mathbf{\Delta}$ ) $=3.6 \mathrm{~cm}$ in M1 and $4.6 \mathrm{~cm}$ in M2; M-Low $($ dotted line,$\times)=4.4 \mathrm{~cm}$ in M1 and $3.5 \mathrm{~cm}$ in M2; and M-High (full line, $\times$ ) $=4.4 \mathrm{~cm}$ in M1 and $4.7 \mathrm{~cm}$ in M2. Error bars represent twice the standard error of the difference.

PGSH from $\mathrm{S}$ to $\mathrm{L}$ and further to $\mathrm{M}$ significantly $(P<0.001)$ increased GDMI (Table 2$)$. During M2, a significant interaction was observed between M1 and M2 for GDMI. The S-Low cows had the lowest GDMI (15.3 kg of DM/cow per day), even though not significantly different from L-Low (Table 2). The L-High cows recorded the highest GDMI $(17.8 \mathrm{~kg}$ of $\mathrm{DM} /$ cow per day) but were not significantly different from S-High and M-High (Table 2). The M-Low cows were intermediate $(16.3 \mathrm{~kg}$ of $\mathrm{DM} /$ cow per day). The GDMI increased $(P<0.001)$ for cows on the high $(17.5 \mathrm{~kg}$ of $\mathrm{DM} / \mathrm{d})$ compared with the low treatments (15.7 kg of DM/d). Between M1 and M2, GDMI increased by $3.6 \mathrm{~kg}$ of DM for the S-High cows, $2.8 \mathrm{~kg}$ of DM for the L-High cows, and $2.1 \mathrm{~kg}$ of DM for the S-Low cows. The L-Low, M-Low, and M-High cows had an increase in GDMI of $1.0 \mathrm{~kg}$ of DM during this period (Table 5). 
Table 5. Effect of change in postgrazing sward height (PGSH) on the short-term response in grass DM and growth and milk production (expressed as unité fourragère lait; UFL) intake, and plasma between measurement period 1 (M1; 59 DIM) and 2 (M2; 80 DIM)

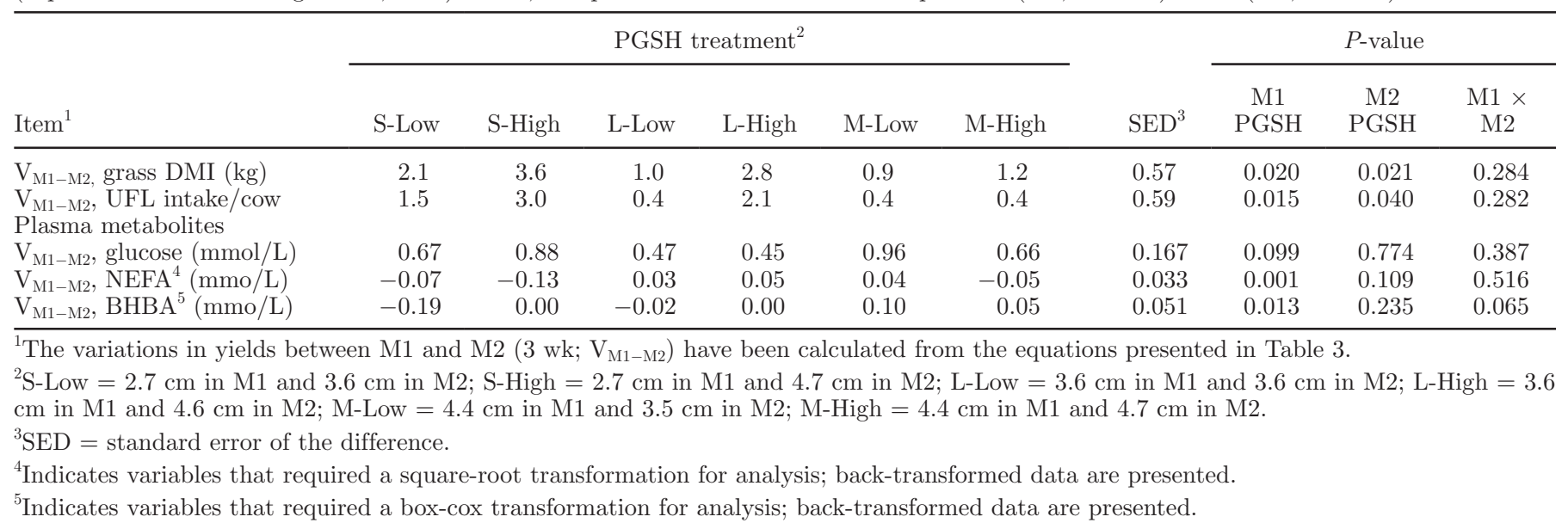

\section{Energy Balance}

During M1, the UFL requirement of cows on the $\mathrm{S}$ treatment was lower $(14.9 \mathrm{UFL} / \mathrm{d} ; P<0.001)$ compared with the L (17.0 UFL/d) and M (17.4 UFL/d) treatments. Increasing PGSH increased $(P<0.001)$ UFL intake to $13.7,15.5$, and $16.5 \mathrm{UFL} / \mathrm{d}$, respectively, from the $\mathrm{S}$ to $\mathrm{L}$ and $\mathrm{M}$ treatments. However, the energy balance values did not differ significantly across treatments $(-1.20 \mathrm{UFL} / \mathrm{d}$; Table 2$)$. In M2, the cows in the high treatment had a greater $(P<0.001)$ UFL requirement (16.1 UFL/d) and UFL intake (17.2 UFL/d) than those in the low treatment (15.0 and 15.7 $\mathrm{UFL} / \mathrm{d}$, respectively). Energy balance was not different between the high and low treatments $(0.9 \mathrm{UFL} / \mathrm{d})$. All treatments increased UFL intake between M1 and M2 (Table 5).

\section{Blood Metabolites}

In M1, plasma NEFA concentration was higher in the $\mathrm{S}$ treatment $(0.35 \mathrm{mmol} / \mathrm{L} ; P<0.001)$ than in the $\mathrm{L}$ and $\mathrm{M}$ treatments $(0.25 \mathrm{mmol} / \mathrm{L}$, on average). During M2, plasma NEFA concentration was greater $(P<0.05)$ in low $(0.28 \mathrm{mmol} / \mathrm{L})$ than in high $(0.22$ $\mathrm{mmol} / \mathrm{L})$ treatments. Between M1 and M2, the S-High cows had the greatest decrease in NEFA concentration (Table 5). On average, animals from $\mathrm{S}$ in $\mathrm{M} 1$ recorded a decreased NEFA concentration $(P<0.001)$ between M1 and M2 $(-0.10 \mathrm{mmol} / \mathrm{L})$ when compared with the mean increase recorded for animals from $\mathrm{L}$ and $\mathrm{M}$ in M1 (0.02 $\mathrm{mmol} / \mathrm{L}$, on average). The reduction in BHBA was most pronounced in S-Low and the increase most pronounced for M-Low (Table 5).

\section{Grazing Behavior}

During M1, no effect of PGSH was observed on grazing time $(629 \mathrm{~min} / \mathrm{d})$, number of grazing bites $(38,807$ per day), grazing bites per minute (62 bites/min), or idling time $(421 \mathrm{~min} / \mathrm{d})$. Intake rate $(\mathrm{GDMI} / \mathrm{min})$ was greater $(P<0.01)$ for the $\mathrm{M}$ cows $(26.8 \mathrm{~g}$ of $\mathrm{DM} / \mathrm{min})$ when compared with $\mathrm{S}$ and L cows, which were similar $(22.0 \mathrm{~g} / \mathrm{min})$. The $\mathrm{M}$ cows had the greatest intake per bite $(0.44 \mathrm{~g} /$ bite; $P<0.05)$, whereas the $\mathrm{S}$ cows had the lowest $(0.33 \mathrm{~g} / \mathrm{bite})$; the $\mathrm{L}$ cows were intermediate $(0.39 \mathrm{~g} /$ bite $)$. The $\mathrm{M}$ cows had the greatest ruminating time $(418 \mathrm{~min} / \mathrm{d} ; P<0.05)$, the $\mathrm{S}$ cows the lowest $(368 \mathrm{~min} / \mathrm{d})$, and the $\mathrm{L}$ cows were intermediate $(387$ $\min / \mathrm{d})$.

During M2, cows in high treatments had a greater intake rate per minute $(31.3 \mathrm{~g} / \mathrm{min} ; P<0.01)$ and per bite $(0.48 \mathrm{~g} / \mathrm{bite} ; P<0.05)$ than the low treatments $(27.7 \mathrm{~g} / \mathrm{min}$ and $0.42 \mathrm{~g} /$ bite, respectively). Cows in high treatments also had higher ruminating time (479 $\mathrm{min} / \mathrm{d} ; P<0.01)$ in comparison to low treatments (439 $\min / \mathrm{d})$.

The change in grazing behavior parameters between M1 and M2 are presented in Table 6 . Within the high treatment of M2, the lower PGSH imposed in M1 resulted in a greater reduction in the number of grazing bites per day in M2 $(-2,079,-3,115$, and $-4,590$ bites/d for M-High, L-High, and S-High, respectively). In contrast, the L-Low cows had the greatest increase in number of grazing bites per day (Table 6). Within the high treatments, the number of grazing bites per minute increased in the M-High treatment ( 0.38 bites/ $\min )$, whereas it decreased in the L-High $(-0.12$ bites/ min) and further decreased in S-High ( -3.36 bites/ min) treatments. Intake per minute and intake per bite increased the most for the S-High and L-High cows (Table 6). On average, the lower PGSH imposed in M1 resulted in a greater increase in ruminating time $(P$ $<0.001)$; the higher PGSH imposed in M2 resulted in a greater increase in ruminating time $(P<0.01)$. As a result, the M-Low cows had the lowest increase 
Table 6. Effect of change in postgrazing sward height (PGSH) on the short-term response $\left(\mathrm{V}_{\mathrm{M} 1-\mathrm{M} 2}{ }^{1}\right)$ in dairy cow behavior parameters between measurement period 1 (M1; April 4-24) and 2 (M2; April 25-May 15)

\begin{tabular}{|c|c|c|c|c|c|c|c|c|c|c|}
\hline \multirow[b]{2}{*}{ Item } & \multicolumn{6}{|c|}{ PGSH treatment $^{2}$} & \multirow[b]{2}{*}{$\mathrm{SED}^{3}$} & \multicolumn{3}{|c|}{$P$-value } \\
\hline & S-Low & S-High & L-Low & L-High & M-Low & M-High & & $\begin{array}{c}\text { M1 } \\
\text { PGSH }\end{array}$ & $\begin{array}{c}\text { M2 } \\
\text { PGSH }\end{array}$ & $\begin{array}{c}\text { M1 } \times \\
\text { M2 }\end{array}$ \\
\hline $\mathrm{V}_{\mathrm{M} 1-\mathrm{M} 2}$, grazing bites (no./d) & 2,344 & $-4,590$ & 4,245 & $-3,115$ & 2,081 & $-2,079$ & $1,521.5$ & 0.845 & 0.015 & 0.808 \\
\hline $\mathrm{V}_{\mathrm{M} 1-\mathrm{M} 2}$, grazing bites/min & 3.45 & -3.36 & 3.44 & -0.12 & 2.69 & 0.38 & 1.201 & 0.739 & 0.032 & 0.534 \\
\hline $\mathrm{V}_{\mathrm{M} 1-\mathrm{M} 2}$, intake/min $(\mathrm{g})$ & 3.3 & 6.9 & 1.9 & 7.4 & 1.1 & 2.4 & 0.88 & 0.276 & 0.005 & 0.172 \\
\hline $\mathrm{V}_{\mathrm{M} 1-\mathrm{M} 2}$, idling time $(\mathrm{min} / \mathrm{d})$ & -140 & -106 & -58 & -54 & -32 & 3 & 21.1 & 0.032 & 0.471 & 0.897 \\
\hline
\end{tabular}

${ }^{1}$ The variations in yields between M1 and M2 (3 wk) have been calculated from the equations presented in Table 3.

${ }^{2} \mathrm{~S}-\mathrm{Low}=2.7 \mathrm{~cm}$ in $\mathrm{M} 1$ and $3.6 \mathrm{~cm}$ in M2; S-High $=2.7 \mathrm{~cm}$ in M1 and $4.7 \mathrm{~cm}$ in M2; L-Low $=3.6 \mathrm{~cm}$ in M1 and $3.6 \mathrm{~cm}$ in M2; L-High = 3.6 $\mathrm{cm}$ in M1 and $4.6 \mathrm{~cm}$ in M2; M-Low $=4.4 \mathrm{~cm}$ in M1 and $3.5 \mathrm{~cm}$ in M2; M-High $=4.4 \mathrm{~cm}$ in M1 and $4.7 \mathrm{~cm}$ in M2.

${ }^{3} \mathrm{SED}=$ standard error of the difference.

in ruminating time and S-High cows had the greatest (Table 6).

\section{$B W$ and $B C S$}

Mean BW in M1 was not significantly affected by treatment (450, SED $4 \mathrm{~kg}$, on average). Mean BCS was the lowest on the $\mathrm{S}$ treatment $(2.77$, SED 0.019; $P<$ 0.01 ) and the highest on the $\mathrm{M}$ treatment (2.89). The $\mathrm{L}$ treatment was intermediate (2.82). Treatment in M2 did not affect mean BCS (2.74, SED 0.027). Mean BW in $\mathrm{M} 2$ was $-8 \mathrm{~kg}(P<0.01)$ for cows previously in $\mathrm{L}$ than the mean BW of cows from S and M (466, SED 2 $\mathrm{kg}$, on average).

\section{DISCUSSION}

The present experiment investigated the dairy cow's short-term response to variations in plane of nutrition dictated by the PGSH imposed. The changes in milk production and composition reported in the present experiment are a function of the PGSH imposed preceding and following the change-over in experimental treatment. The results herein indicate that dairy cows are highly responsive to an increase or decrease in the plane of nutrition offered and alter their milk production accordingly. The difference in effective DHA resulting from the PGSH imposed was greater than the actual difference in herbage DMI. For example, in M1, this was expected because DHA was calculated above $2.7 \mathrm{~cm}$, whereas L and M cows only defoliated swards to 3.6 and $4.4 \mathrm{~cm}$, respectively.

\section{Equations to Predict Milk and Milk Solids Changes}

The equations to predict milk production and composition changes provide a practical decision tool for grass-based dairy farms to estimate the change in animal production when PGSH may change around the tenth week of lactation. As with O'Neill et al. (2013), the negative intercept in the equations to predict milk yield and milk solids changes reflect the stage of lactation (following peak) at the time of the change-over (Broster and Broster, 1984). The present study examined data that were obtained in a limited time period. Different milk production changes may be expected if the period of experimentation was extended (both M1 and M2), particularly because the carryover effect of M1 treatment in M2 may reduce over time (Delaby et al., 2009; Ganche et al., 2013a). Stage of lactation affects milk yield. All cows in the present study were in early lactation; therefore, it is expected that the equations coefficients presented in our study would vary with stage of lactation. The animal's response to changes in PGSH may also depend on the proportion of primiparous cows in the herd, which affect peak milk yield (McEvoy et al., 2009), and on animal genetic potential, where the partitioning of the available energy between milk production and body reserves can differ (Yan et al., 2006). Finally, the equations established in the present study focused on grazing dairy cows offered pasture only; a coefficient for herbage substitution may be required in future grazing experiments including supplements in the diet (McEvoy et al., 2009). The prediction of the variation in animal production variables established in our experiment provides guidance on the best approach to grazing and feeding management of the dairy cow during periods of fluctuation in grass supply.

\section{Effects on Animal Production when Changing from a Severe to a High PGSH in Early Lactation}

The change-over occurred at d 69 of the lactation, on average. Almost $90 \%$ of the cows were in the postpeak 
stage of lactation. Previous studies have shown that cow's milk production peaks between wk 5 and 7 after calving (Ingvartsen and Andersen, 2000; O'Neill et al., 2013 ) and then declines by approximately $2 \%$ per week (Delaby et al., 2001; unsupplemented cows). When cows grazed to $2.7 \mathrm{~cm}$ during M1 and then grazed to $4.7 \mathrm{~cm}$ in M2 (S-High), their milk yield increased. This was in contrast to all other treatments, where a reduction in milk yield was observed. A theoretical $2 \%$ loss would equate to a reduction of $0.43 \mathrm{~kg}$ of milk/wk using the milk yield achieved by the S-High cows in M1. Given that the S-High cows increased their milk yield by 0.68 $\mathrm{kg}$ over $3 \mathrm{wk}(0.23 \mathrm{~kg} / \mathrm{wk})$, at this point of lactation it indicates that these animals were severely restricted by nutrient supply during M1. Burke et al. (2010) severely restricted the pasture allowance of dairy cows at the beginning of the breeding season to reduce DMI from $14.3 \mathrm{~kg}$ of DM/cow per day (prior experiment) to $8.0 \mathrm{~kg}$ of $\mathrm{DM} /$ cow per day over $14 \mathrm{~d}$. This resulted in $3 \% \mathrm{FCM}$ loss over the 2 experimental weeks. At d 15, cows were offered a generous pasture allowance to reach a DMI of $16 \mathrm{~kg}$ of DM/cow per day. The milk yield response obtained from this change of regimen was $+12 \%$ milk yield in $12 \mathrm{~d}$; the doubled pasture allowance following the short restriction period is the reason for the extremely large milk yield change. Gross et al. (2011) also found an increase in milk production when the diet of cows was altered after a 3 -wk restriction in the dietary energy density. The increase in PGSH in S-High resulted in a greater DHA (4.8 $\mathrm{kg}$ of $\mathrm{DM} /$ cow between M1 and M2); as a result, the cows responded and substantially increased their GDMI by $3.8 \mathrm{~kg}$ of DM (i.e., $1.3 \mathrm{~kg}$ of $\mathrm{DM} /$ cow per week) through achieving higher GDMI per minute and GDMI per bite, which supported an increase in milk yield. Intake per bite was previously determined as the dominant animal variable that influences short-term grass intake (Hodgson, 1981) and subsequent daily GDMI (Barrett et al., 2001). The positive milk yield change on this treatment indicates that the potential milk secretion of the mammary gland was not completely compromised by the restrictive grazing regimen imposed in M1.

A delay exists before quiescent mammary secretory alveoli are reactivated (Vetharaniam et al., 2003) and can produce milk to a similar level that could have been achieved if their diet was not restricted in early lactation. When the weekly milk yields were examined, it showed that milk yield of S-High cows increased by only $1 \%$ between experimental wk 3 and 4 (Figure 2), with a further increase of $1 \%$ from wk 4 to 5 of M2; but an increase of $3 \%$ was observed between wh 5 and 6 , indicating that it took almost $2 \mathrm{wk}$ before the quiescent cells were fully reactivated again. The positive change in milk yield indicates that animals are able to com- pensate for short-term energy restriction when they are subsequently offered a higher nutrient supply.

Given the high energy content of the herbage offered, the change in UFL intake followed the same trend as GDMI across all treatments. Increasing PGSH in M2 increased the energy intake of the S-High cows by $20 \%$ between M1 and M2, which facilitated an increase in milk yield and milk solids yield. Coulon and Rémond (1991) stated that an increased dietary energy supply results in an increase in the nutrients available to the udder for synthesis of milk constituents. The change in milk solids yield during M2 showed a similar trend to the changes in milk yield, as little difference was observed in milk composition. The increase in dietary energy supply was associated with a reduction in circulating plasma NEFA, particularly in S-High, and confirms that the $\mathrm{S}$ cows were previously underfed in M1. In agreement with the present findings, Gross et al. (2011) reported a similar reduction in plasma NEFA concentration (120 DIM) during the realimentation period that followed severe feed restriction.

\section{Effects on Animal Production when Changing from High to Low PGSH in Early Lactation}

Reducing PGSH from 4.4 to $3.5 \mathrm{~cm}$ (M-Low) resulted in a pronounced reduction in milk yield and composition during the period of investigation. The mean reduction in milk yield between M1 and M2 equated to an equivalent of $5 \%$ per week, which is greater than that anticipated (Delaby et al., 2001). From the examination of weekly milk yields it is evident that the reduction in milk yield was immediate. Milk yield decreased by $6 \%$ per week from wk 3 to 4 (M1 to M2) and a further $10 \%$ per week reduction was observed between wk 4 and 5 ; the reduction was less pronounced from wk 5 to 6 ( $-3 \%$ per week). Dry matter intake is a major factor limiting milk production in early lactation (Kertz et al., 1991). Peak GDMI occurs between wk 8 and 22 of lactation (Ingvartsen and Andersen, 2000). Grazing to $4.2 \mathrm{~cm}$ in early lactation allowed these cows to achieve a DMI comparable to cows of similar genetic merit for milk yield with adequate feed allowance in early lactation (Lewis et al. 2011; McCarthy et al., 2013). Lewis et al. (2011) outlined a $1 \mathrm{~kg}$ of DM/wk increase in DMI up to 84 DIM; thus, when DMI of the M-Low cows was measured in M2 (85 DIM) it was expected to be approximately $3 \mathrm{~kg}$ of $\mathrm{DM} /$ cow higher than in M1. However, it was only $0.9 \mathrm{~kg} /$ cow greater. When the M-Low cows became restricted by a lower PGSH, even though they increased their time grazing between M1 and M2, it did not compensate for the lower intake per bite (Gibb et al., 1997). The reduced DMI results in a lower energy intake, which gave rise 
to a large reduction in milk solids yield, similar to that observed by Pérez-Prieto et al. (2011).

Decreasing PGSH from early spring to early summer has previously been shown to reduce the quality of herbage consumed by the animals and, consequently, decreased animal production (O'Donovan et al., 2004; Kennedy et al., 2007). This is due to the fact that animals are restricted from grazing into the lower strata, which is composed of accumulated stem, dead materials, and growing pseudostem. The current study did not show any differences in herbage quality between swards. It can be hypothesized that if our study had been conducted later in the spring, at the beginning of the plant reproductive phase, it may have resulted in differences in herbage quality and potentially influenced subsequent animal production.

\section{Effects of a Moderate Increase in PGSH Compared with Maintaining a Constant PGSH}

Previous recommendations have been to maintain a constant PGSH $(4.0 \mathrm{~cm})$ throughout the spring and main grazing season (McEvoy et al., 2008; Wims et al., 2010). However, the present experiment found that when PGSH remained constant between M1 and M2, both the L-Low and M-High cows had a similar 10\% reduction in milk yield and milk component yields during M2 ( -3.5 and $-3 \%$ per week, respectively). It is hypothesized from the present results that the quantity of nutrients available in M2 was not entirely sufficient to meet animal requirements at this stage of lactation. Maintaining similar PGSH throughout M1 and M2 was associated with a similar DHA in M1 and M2, thus the L-Low and M-High animals were unable to increase GDMI and UFL intake sufficiently, which subsequently reduced milk yield and milk composition. Animals from the L-Low and M-High treatments all consumed herbage of similar quality (1.00 UFL in M2). Therefore, a similar decrease in milk yield between the 2 treatments was not surprising. In comparison, increasing PGSH from 2.7 to $3.5 \mathrm{~cm}$ (S-Low) or from 3.6 to $4.5 \mathrm{~cm}$ (LHigh) gave the animal the opportunity to increase energy intake; this resulted in relative low mean weekly milk yield reduction (1.5 and $1.6 \%$ per week, respectively). Despite the positive response in S-High, this treatment recorded the lowest cumulative milk solids yield over the 6 experimental weeks, but was not significantly different from S-Low. The best performance was recorded in treatments L-High, M-Low, and M-High.

\section{Practical Implications}

Our short-term experiment delivers novel knowledge on dairy cow responses to changes in PGSH when of- fered a pasture-only diet. The current experiment demonstrated that the mammary gland of the dairy cow rapidly adapts to the short-term changes in nutrient input, which is governed by the change in feed regimens imposed. Management practices can be adjusted in line with grass growth, such as the removal of grazing area when grass surpluses arise or increased input of nitrogen fertilizer when grass growth is low. In periods of unpredictable grass growth fluctuations, such as at the end of the spring, the knowledge that the dairy cow is able to adapt its behavior and production offers greater flexibility to the system. Ganche et al., (2013a,b) have shown that imposing a very severe feed restriction for the first $10 \mathrm{wk}$ of lactation reduces total lactation milk solids yield. Although a positive animal production response was achieved when cows changed from a highly restricted regimen in early lactation to a high plane of nutrition from 70 DIM, the 6-wk cumulative milk yield remained lower than cows originally assigned to $\mathrm{L}$ and M. The 6 -wk cumulative production of cows grazing to $4.2 \mathrm{~cm}$ in early lactation was similar to that of cows grazing to $3.5 \mathrm{~cm}$. This reconfirms that a PGSH of $3.5 \mathrm{~cm}$ can be imposed in early spring, as previously recommended by Ganche et al. (2013a; 2013b), as it strikes a balance between high grass utilization and per-cow production in early lactation. Furthermore, when PGSH is increased to 4.0 to $4.5 \mathrm{~cm}$ after the first 2 grazing rotations, cows can express their requirement for higher DMI (Lewis et al., 2011) and can convert their additional energy intake into milk output.

\section{REFERENCES}

AOAC International. 1995. Official Methods of Analysis. Vol. 1, 16th ed. AOAC Int., Arlington, VA.

Barrett, P. D., A. S. Laidlaw, C. S. Mayne, and H. Christie. 2001. Pattern of herbage intake rate and bite dimensions of rotationally grazed dairy cows as sward height declines. Grass Forage Sci. $56: 362-373$.

Beaumont, R., J. P. Dulphy, D. Sauvant, F. Meschy, J. Aufrere, and J. L. Peyraud. 2007. Valeur alimentaire des fourrages et des matieres premieres: Tables et prévision. Pages 149-180 in Alimentation des Bovins, Ovins et Caprins. QUAE Editions. Institut National de Recherche Agronomique, Versailles, France.

Broster, W. H., and V. J. Broster. 1984. Reviews of the progress of dairy science: Long term effects of plane of nutrition on the performance of the dairy cows. J. Dairy Res. 51:149-196.

Burke, C. R., Y. J. Williams, L. Hofmann, J. K. Kay, C. V. C. Phyn, and S. Meier. 2010. Effects of an acute feed restriction at the onset of the seasonal breeding period on reproductive performance and milk production in pasture-grazed dairy cows. J. Dairy Sci. 93:1116-1125.

Coulon, J. B., P. D'Hour, and M. Petit. 1988. Influence of transition feeding pattern on milk production at the turnout of cows to pasture. Livest. Prod. Sci. 20:119-134.

Coulon, J. B., and B. Rémond. 1991. Variations in milk output and milk protein content in response to the level of energy supply to the dairy cow: A review. Livest. Prod. Sci. 29:31-47.

Delaby, L., P. Faverdin, G. Michel, C. Disenhaus, and J. L. Peyraud. 2009. Effect of different feeding strategies on lactation performance of Holstein and Normande dairy cows. Animal 3:891-905. 
Delaby, L., J. L. Peyraud, and R. Delagarde. 2001. Effect of the level of concentrate supplementation, herbage allowance and milk yield at turn-out on the performance of dairy cows in mid lactation at grazing. Anim. Sci. 73:171-181.

Dillon, P. 1993. The use of n-alkanes as markers to determine intake, botanical composition of available or consumed herbage in studies of digesta kinetics with dairy cows. PhD Thesis. National University of Ireland, Dublin, Ireland.

Dillon, P., S. Crosse, G. Stakelum, and F. Flynn. 1995. The effect of calving date and stocking rate on the performance of springcalving dairy cows. Grass Forage Sci. 50:286-299.

Dillon, P., and G. Stakelum. 1989. Herbage and dosed alkanes as a grass management technique for dairy cows. Ir. J. Agric. Food Res. 8:104.

Faverdin, P., R. Delagarde, L. Delaby, and F. Meschy. 2007. Alimentation des vaches laitières. Pages 23-55 in Alimentation des Bovins, Ovins et Caprins. QUAE Editions. Institut National de Recherche Agronomique, Versailles, France.

Finneran, E., P. Crosson, M. Wallace, P. O'Kiely, P. D. Forristal, and L. Shalloo. 2010. Simulation modelling of the cost of production and utilizing feeds for ruminants on Irish farms. J. Farm Management 14:95-116.

Friggens, N. C., G. C. Emmans, I. Kyriazakis, J. D. Oldham, and M. Lewis. 1998. Feed intake relative to stage of lactation for dairy cows consuming total mixed diets with a high or low ratio of concentrate to forage. J. Dairy Sci. 81:2228-2239.

Ganche, E., L. Delaby, M. O'Donovan, T. Boland, and E. Kennedy. 2013a. Direct and carryover effect of post-grazing sward height on total lactation dairy cow performance. Animal 7:1390-1400.

Ganche, E., L. Delaby, M. O'Donovan, T. M. Boland, N. Galvin, and E. Kennedy. 2013b. Post-grazing sward height imposed during the first 10 weeks of lactation: Influence on early and total lactation dairy cow production, and spring and annual sward characteristics. Livest. Sci. 157:299-311. http://dx.doi.org/10.1016/j. livsci.2013.08.001.

Gibb, M. J., C. A. Huckle, R. Nuthall, and A. J. Rook. 1997. Effect of sward surface height on intake and grazing behaviour by lactating Holstein Friesian cows. Grass Forage Sci. 52:309-321.

Grainger, C., and G. Wilhelms. 1979. Effect of duration and pattern of underfeeding in early lactation on milk production and reproduction of dairy cows. Aust. J. Exp. Agric. Anim. Husb. 19:395-401.

Gross, J., H. A. van Dorland, R. M. Bruckmaier, and F. J. Schwarz. 2011. Performance and metabolic profile of dairy cows during a lactational and deliberately induced negative energy balance with subsequent realimentation. J. Dairy Sci. 94:1820-1830.

Hodgson, J. 1981. Variation in the surface characteristics of the sward and the short-term rate of herbage intake by calves and lambs. Grass Forage Sci. 36:49-57.

Hurtado-Uria, C., D. Hennessy, L. Shalloo, D. O'Connor, and L. Delaby. 2013. Relationships between meteorological data and grass growth over time in the south of Ireland. Ir. Geogr. http://dx.doi. org/10.1080/00750778.2013.865364. In press.

Ingvartsen, K. L., and J. B. Andersen. 2000. Integration of metabolism and intake regulation: A review focusing on periparturient animals. J. Dairy Sci. 83:1573-1597.

Kennedy, E., M. O'Donovan, F. P. O'Mara, J. P. Murphy, and L. Delaby. 2007. The effect of early-lactation feeding strategy on the lactation performance of spring-calving dairy cows. J. Dairy Sci. 90:3060-3070

Kertz, A. F., L. F. Reutzel, and G. M. Thomson. 1991. Dry matter intake from parturition to midlactation. J. Dairy Sci. 74:2290-2295.

Lewis, E., M. O'Donovan, E. Kennedy, B. O'Neill, and L. Shalloo. 2011. Feeding the dairy cow in spring: Supplementation require- ments and responses. Pages 71-81 in The Irish Dairy Industry: To 2015 and Beyond, Teagasc Natl. Dairy Conf. 2011, Cork, Ireland. Teagasc, Oakpark, Ireland

Lowman, B. G., N. A. Scott, and S. H. Somerville. 1976. Condition scoring of cattle. Bulletin no. 6. East of Scotland College of Agriculture, Edinburgh, UK.

McCarthy, B., L. Delaby, K. M. Pierce, A. Brennan, and B. Horan. 2013. The effect of stocking rate and calving date on milk production of Holstein-Friesian dairy cows. Livest. Sci. 153:123-134.

McEvoy, M., L. Delaby, E. Kennedy, T. M. Boland, and M. O'Donovan. 2009. Early lactation dairy cows: Development of equations to predict intake and milk performance at grazing. Livest. Sci. 122:214221.

McEvoy, M., E. Kennedy, J. P. Murphy, T. M. Boland, L. Delaby, and M. O'Donovan. 2008. The effect of herbage allowance and concentrate supplementation on milk production performance and dry matter intake of spring-calving dairy cows in early lactation. J. Dairy Sci. 91:1258-1269.

Morgan, D. J., G. Stakelum, and J. Dwyer. 1989. Modified neutral detergent cellulase digestibility procedure for use with the fibretec system. Isr. J. Agric. Res. 28:91-92.

Nielsen, N. I., N. C. Friggens, T. Larsen, J. B. Andersen, M. O. Nielsen, and K. L. Ingvartsen. 2007. Effect of changes in diet energy density on feed intake, milk yield and metabolic parameters in dairy cows in early lactation. Animal 1:335-346.

O'Donovan, M., L. Delaby, and J. L. Peyraud. 2004. Effect of time of initial grazing date and subsequent stocking rate on pasture production and dairy cow performance. Anim. Res. 53:489-502.

O'Neill, B. F., E. Lewis, M. O'Donovan, L. Shalloo, N. Galvin, F. J. Mulligan, T. M. Boland, and R. Delagarde. 2013. Predicting grass dry matter intake, milk yield and milk fat and protein yield of spring calving grazing dairy cows during the grazing season. Animal 7:1379-1389.

Pérez-Prieto, L. A., J. L. Peyraud, and R. Delagarde. 2011. Pasture intake, milk production and grazing behaviour of dairy cows grazing low-mass pastures at three daily allowances in winter. Livest. Sci. 137:151-160.

Roche, J. R., C. R. Burke, S. Meier, and C. G. Walker. 2011. Nutrition $\times$ reproduction interaction in pasture-based systems: Is nutrition a factor in reproductive failure? Anim. Prod. Sci. 51:1045-1066.

Rutter, S. M. 2000. 'Graze': A program to analyze recordings of jaw movements of ruminants. Behav. Res. Methods. Instr. Comput. 32:86-92.

Rutter, S. M., R. A. Champion, and P. D. Penning. 1997. An automatic system to record foraging behaviour in free-ranging ruminants. Appl. Anim. Behav. Sci. 54:185-195.

Shalloo, L. 2009. Pushing the barriers on milk production costs/outputs. Pages $13-38$ in Teagasc Natl. Dairy Conf. 2009. 18-19 November 2009, Mullingar and Killarney, Ireland. Teagasc, Oakpark, Ireland.

Vetharaniam, I., S. R. Davis, M. Upsdell, E. S. Kolver, and A. B. Pleasants. 2003. Modeling the effect of energy status on mammary gland growth and lactation. J. Dairy Sci. 86:3148-3156.

Wims, C. M., M. H. Deighton, E. Lewis, B. O'Loughlin, L. Delaby, T, M. Boland, and M. O'Donovan. 2010. Effect of pregrazing herbage mass on methane production, dry matter intake, and milk production of grazing dairy cows during the mid-season period. J. Dairy Sci. 93:4976-4985.

Yan, T., C. S. Mayne, T. W. J. Keady, and R. E. Agnew. 2006. Effects of dairy cow genotype with two planes of nutrition on energy partitioning between milk and body tissue. J. Dairy Sci. 89:1031-1042. 